\title{
SINGLE-NUCLEOTIDE POLYMORPHISM OF TNFSF4 (RS2205960) OF SYSTEMIC LUPUS ERYTHEMATOSUS PATIENTS IN BANDUNG, INDONESIA
}

\author{
ANGELA APRILIA KARYADI' ${ }^{1}$ ERICA WILLY1 ${ }^{1}$, GABRIEL BAGUS KENNARDI ${ }^{2}$, MUHAMMAD SYAWAL PRATAMA ${ }^{3}$, \\ DESI RESKI FAJAR' ${ }^{1}$ LANIYATI HAMIJOYO ${ }^{2,4}$, RIEZKI AMALIA ${ }^{3,5}$, MELISA INTAN BARLIANA ${ }^{1,5}$
}

1Department Biological Pharmacy, Faculty of Pharmacy, Padjadjaran University, Jl. Raya Bandung-Sumedang KM 21, Jatinangor, 45363, Indonesia, ${ }^{2}$ Immunology Study Center, Faculty of Medicine, Padjadjaran University, Jl. Raya Bandung-Sumedang KM 21, Jatinangor, 45363, Indonesia, ${ }^{3}$ Department of Pharmacology and Clinical Pharmacy, Padjadjaran University, Jl. Raya Bandung-Sumedang KM 21, Jatinangor, 45363, Indonesia, ${ }^{4}$ Department of Internal Medicine Faculty of Medicine, Padjadjaran University, Hasan Sadikin Hospital, Jl. Pasteur 38 Bandung, 40161, Indonesia, ${ }^{5}$ Center of Excellence in Higher Education for Pharmaceutical Care Innovation, Padjadjaran University, Jl.

Raya Bandung-Sumedang KM 21, Jatinangor, 45363, Indonesia Email: melisa.barliana@unpad.ac.id

Received: 08 Aug 2021, Revised and Accepted: 15 Aug 2021

\section{ABSTRACT}

Objective: This study aimed to determine the genotype distribution of the TNFSF4 (Tumor Necrosis Factor Superfamily 4) gene rs2205960 in Systemic Lupus Erythematosus (SLE) patients in Bandung, West Java, Indonesia.

Methods: This was a cross-sectional study; 84 genomic DNA samples were amplified, electrophoresed, then analyzed by DNA sequencing.

Results: The genotype distribution of the TNFSF4 gene rs2205960 in SLE patients showed that from 84 DNA samples, 55 patients are GG (65.48\%), 25 patients are GT $(29.76 \%)$, and 4 patients are TT (4.76\%).

Conclusion: Results indicate that SLE patients in Bandung have a genotype distribution of the TNFSF4 rs2205960 gene that fulfills the HardyWeinberg equilibrium.

Keywords: Bandung, Single-nucleotide polymorphism, RS2205960, Systemic lupus erythematosus, TNFSF4

(C) 2021 The Authors.Published by Innovare Academic Sciences Pvt Ltd. Thisis an open access article under the CCBYlicense (https://creativecommons.org/licenses/by/4.0/) DOI: https://dx.doi.org/10.22159/ijap.2021.v13s4.43827 Journal homepage: https://innovareacademics.in/journals/index.php/ijap

\section{INTRODUCTION}

Systemic Lupus Erythematosus (SLE) is a chronic inflammatory autoimmune disease with various clinical manifestations affecting multiple organ systems [1]. SLE patients experience a loss of selftolerance due to an abnormal immunological function, which leads to the formation of immune complexes that can damage tissues and characterized by the production of autoantibodies, activation of the complement system, and the involvement of genetic and environmental components [1,2].

The cause of SLE is very multifactorial, between various genetic and environmental factors that contribute to disease susceptibility [3]. In recent years, many studies have shown the relationship between polymorphisms of several genes with SLE susceptibility, one of which is the Tumor Necrosis Factor Superfamily 4 (TNFSF4) gene. This gene is located in chromosome 1 at position 25 (1q25). The TNFSF4 gene encodes OX40L, a ligand for the OX40 receptor, which is a member of the tumor necrosis factor (TNF) superfamily that is expressed on antigen-presenting cells, such as B cells, dendritic cells, macrophages, mast cells, endothelial vascular cells, and natural killer cells [4-8].

Single-nucleotide polymorphism (SNP) of the TNFSF4 gene rs2205960 has the most significant association in the TNFSF4 region in SLE patients, according to Genome-Wide Association Studies (GWAS) conducted by Chang et al. (2019). This intronic SNP is located $38.6 \mathrm{~kb}$ upstream of TNFSF4 and implicated as a cis-acting factor for transcription [8-10]. SNP rs2205960 (G>T) causes an increase in OX40L expression, which influences the development of SLE disease. Overexpression of OX40L may increase the stimulation of $\mathrm{CD} 4^{+} \mathrm{T}$ helper effector cells and increase the response of follicular $\mathrm{T}$ helper cells whose function is to help B cells proliferate and form antibodies causing inflammation and autoimmunity in specific organs [11-13]. The OX40L signaling suppresses the generation and function of interleukin-10 (IL10)-producing CD4+type 1 regulatory T cells, which play an important role in maintaining peripheral resistance [14]

According to the meta-analysis conducted by Wang et al. (2019), the TT genotype of the TNFSF4 rs2205960 increases the risk of SLE with a significant degree of association [11]. Another study stated that the $\mathrm{T}$ allele of TNFSF4 rs2205960 had a significant association in SLE patients from Asian, Caucasian, Hispanic, and Mexican races [10,1219]. These results showed the influence of race and ethnicity on SNP. However, research on TNFSF4 gene polymorphisms, especially rs2205960 in SLE patients in Indonesia, has not been reported. Based on this background, this study identified the gene polymorphism of TNFSF4 rs2205960 and analyze the allele and genotype frequencies in SLE patients in Bandung using the direct sequencing method.

\section{MATERIALS AND METHODS}

\section{Subjects}

Blood samples from 84 patients were collected from the Hasan Sadikin Hospital in Bandung, Indonesia. Patients who were included in this study were female patient's aged 18-65 y diagnosed with SLE. Patients were willing to participate in the research and agreed to sign the informed consent. Patients excluded from this study were SLE patients with incomplete treatment data or medical records that could not be traced and patients who were not willing to participate in the study. This study protocol was approved by the Health Research Ethics Committee Universitas Padjadjaran (reference no. 128/UN6. KEP/EC/2020).

\section{DNA isolation}

DNA isolation was done using Geneaid ${ }^{\mathrm{TM}}$ DNA Isolation Kit (Geneaid ${ }^{\mathrm{TM}}$, New Taipei City, Taiwan), which is based on the precipitation method. Extracted DNA samples were then stored at$20^{\circ} \mathrm{C}$ until further use. 


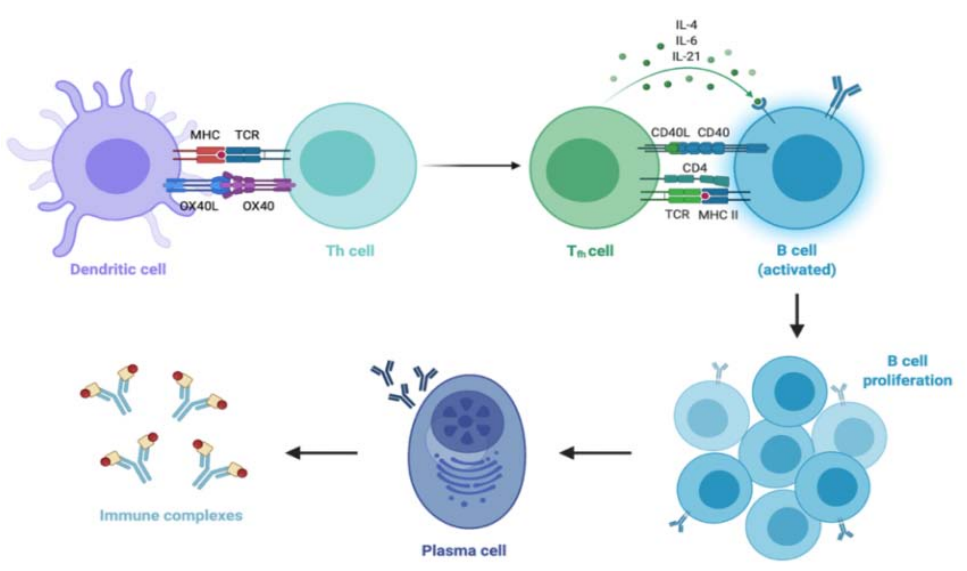

Fig. 1: Higher expression of OX40L and its interaction with OX40 correlates with the formation of immune complexes in SLE (created with BioRender.com)

\section{Single-nucleotide polymorphism analysis}

DNA samples were amplified using Promega GoTaq ${ }^{\circledR}$ Green PCR Master Mix (Promega, Fitchburg, Wisconsin). A total volume of $50 \mu \mathrm{l}$ of each PCR reaction mixtures was prepared, which contained $2 \mu \mathrm{L}$ DNA template, primer forward and reverse each $1 \mu \mathrm{L}$, Promega GoTaq ${ }^{\circledR}$ Green PCR Master Mix $25 \mu \mathrm{L}$, and nuclease-free water $21 \mu \mathrm{l}$. Primers used in this study are based on research by Lu et al. in 2016 [20]. The two primer sets were as follows: forward 5'AACCTTGGTCTCCTATAATGGGTACTCT-3' and reverse 5'GACTTTTTCCCTTTGTCATTTCAG-3 to detect TNFSF4 polymorphic gene. The expected amplicon size was $162 \mathrm{bp}$. Amplification process was carried out in a Bio-Rad T100 ${ }^{\mathrm{TM}}$ Thermal Cycler. PCR reaction was initiated with an early denaturation at $95^{\circ} \mathrm{C}$ for $3 \mathrm{~min}$, and 35 cycles of denaturation at $95{ }^{\circ} \mathrm{C}$ for $30 \mathrm{~s}$, followed by annealing at $58,8{ }^{\circ} \mathrm{C}$ for $30 \mathrm{~s}$, and extension at $72{ }^{\circ} \mathrm{C}$ for $1 \mathrm{~min}$. The final step is a cycle of $72{ }^{\circ} \mathrm{C}$ final extension for $5 \mathrm{~min}$. Furthermore, the polymorphism of TNFSF4 rs2205960 was determined using Sanger sequencing method (1 ${ }^{\text {st }}$ BASE, Selangor, Malaysia).

The results of the DNA sequencing were then aligned with the reference sequence of the TNFSF4 gene originating from Homo sapiens chromosome 1, GRCh38. p13 Primary Assembly (https://www.ncbi.nlm.nih.gov/snp/rs2205960). Alignment between the reference sequence and the resulting sequence was performed using the BioEdit 7.2 software.

\section{Statistical analysis}

The genotypic distribution data were then analyzed using the Hardy-Weinberg equilibrium (HWE) equation (HWE, $d f=1$ ). The Chi-squared $\left(\chi^{2}\right)$ statistic test was used to analyze if the sample populations fulfill the Hardy-Weinberg equilibrium.

\section{RESULTS}

The results of the sequence alignment can be seen in fig. 2, which shows the similarity between the sample sequences and the reference sequences.

Table 1: Number and percentage of genotype distribution

\begin{tabular}{lll}
\hline Genotype & Total patients (n) & Percentage \\
\hline GG & 55 & $65,48 \%$ \\
GT & 25 & $29,76 \%$ \\
TT & 4 & $4,76 \%$ \\
\hline
\end{tabular}

The genotypic distribution data were then analyzed using the Hardy-Weinberg equilibrium test.

The results of the observed and expected frequency can be seen in table 2 .

Table 2: Distribution and comparison of allele frequency

\begin{tabular}{llllll}
\hline Genotypes & n & G allele & T allele & Observed frequency (n/\%) & Expected frequency (n/\%) \\
\hline GG & 55 & 110 & 0 & $55(65,48)$ & $54,2(64,52)$ \\
GT & 25 & 25 & 25 & $25(29,76)$ & $26,5(31,55)$ \\
TT & 4 & 0 & 8 & $4(4,76)$ & $3,2(3,81)$ \\
Total & 84 & 135 & 33 & $84(100)$ & $84(100)$ \\
\hline
\end{tabular}

A Chi-squared test was conducted to see if the sample populations fulfill the Hardy-Weinberg equilibrium. The rejection of the null hypothesis $\left(\mathrm{H}_{0}\right)$ indicates that there is a change in allele frequency from generation to generation which means that it does not fulfill the Hardy-Weinberg equilibrium, and the acceptance of $\mathrm{H}_{0}$ states that the distribution in the population is consistent with the Hardy-
Weinberg equilibrium [21]. From the calculation results in table 3, the Chi-square value $\left(\chi^{2}\right)$ obtained is 0.2752 , and the p-value is 0.599 $(\mathrm{P}>0.05, \alpha=5 \%)$. These results indicate that the null hypothesis is accepted since it has a smaller $\chi^{2}$ value than the table $\chi^{2}$ and p-value greater than the significance level, which means that this study is consistent with the Hardy-Weinberg equilibrium.

Table 3: Results of chi-square test on the hardy-weinberg equilibrium

\begin{tabular}{|c|c|c|c|c|}
\hline Genotypes & Observed frequency (n/\%) & Expected frequency (n/\%) & $\begin{array}{l}\text { Chi-squared }\left(\chi^{2}\right) \\
\text { value }\end{array}$ & $\begin{array}{l}\text { Chi-squared test p- } \\
\text { value }\end{array}$ \\
\hline Homozygote reference (GG) & $55(65,48)$ & $54,2(64,52)$ & 0.2752 & 0.599 \\
\hline Heterozygote (GT) & $25(29,76)$ & $26,5(31,55)$ & & \\
\hline Homozygote variant (TT) & $4(4,76)$ & $3,2(3,81)$ & & \\
\hline
\end{tabular}



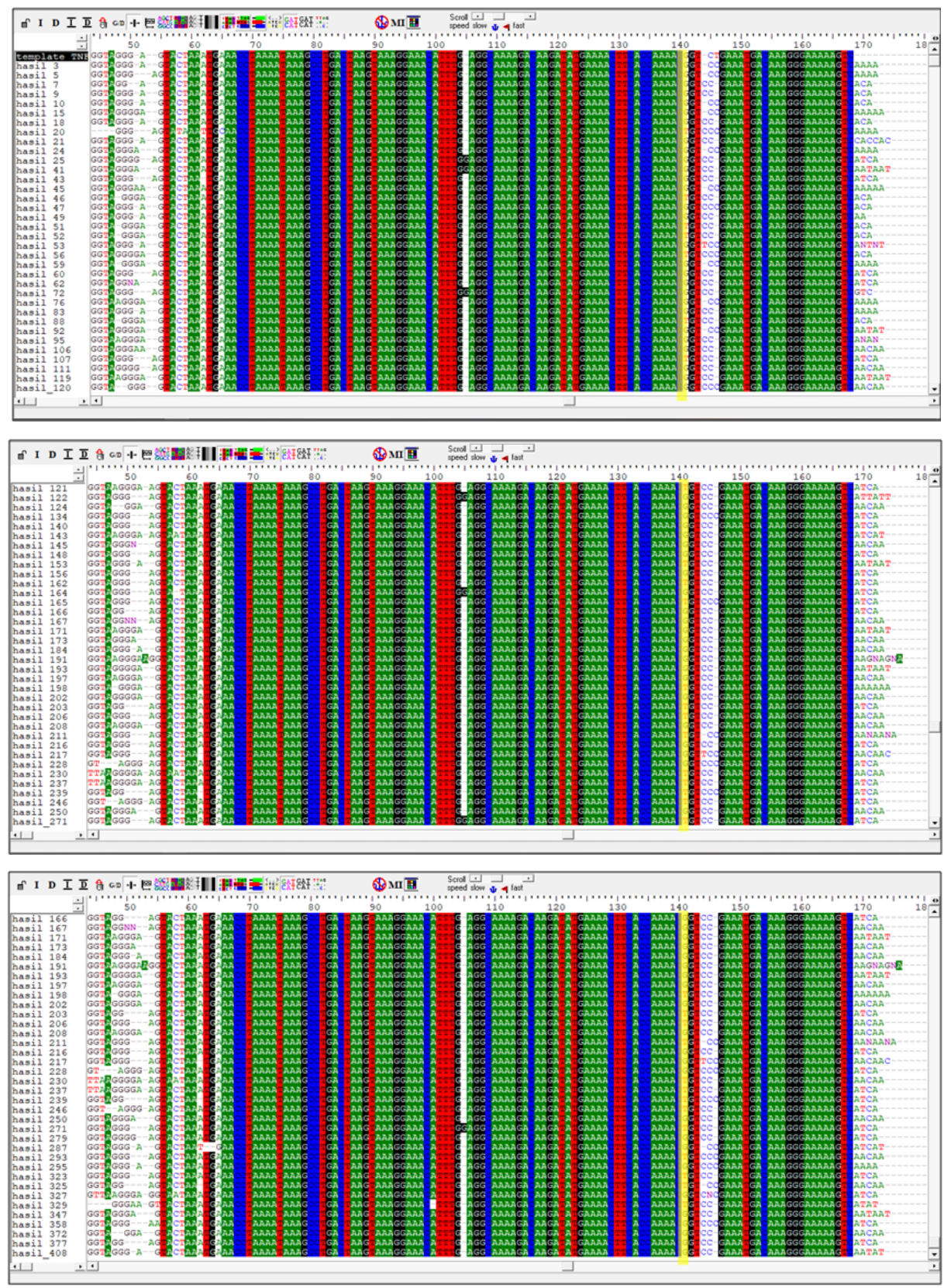

Fig. 2: Alignment results of DNA sequencing (highlighted with yellow is the mutation point/rs2205960)

The information about how to determine results that show the variations obtained can be seen in fig. 3-5.

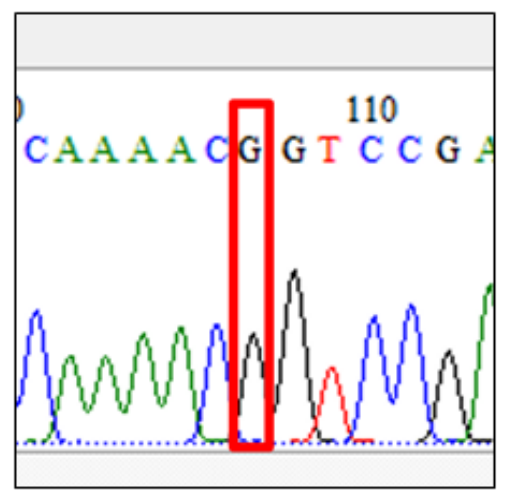

Fig. 3: DNA sequencing results that showed GG genotype

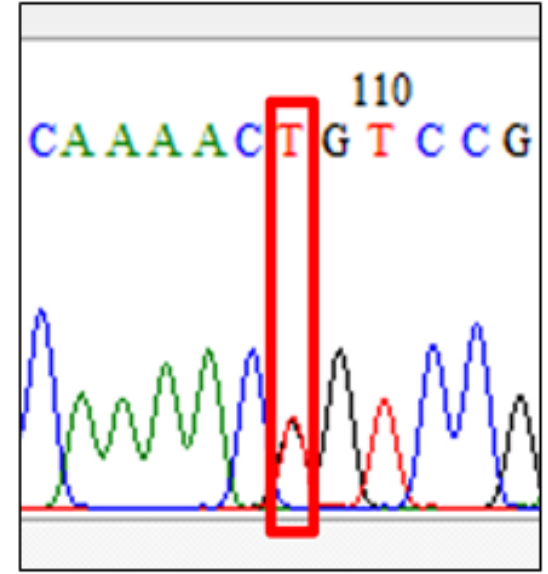

Fig. 4: DNA sequencing results that showed GT genotype 


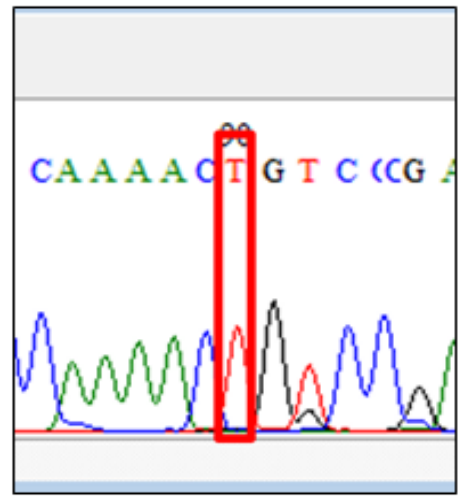

Fig. 5: DNA sequencing results that showed TT genotype

The results of DNA sequencing from 84 samples that were identified, 55 patients (65.48\%) have wild-type GG genotype, 25 patients $(29.76 \%)$ have GT genotype, and 4 patients (4.76\%) have TT genotype (table 1 ).

\section{DISCUSSION}

Research on Chinese ethnicity SLE patients conducted by Chua et al. (2016) showed the distribution of the GG genotype was $50.9 \%$, the GT genotype was $39.9 \%$, and the TT genotype was $9.8 \%$. The same study was also conducted on Malaysian patients with SLE, which showed GG genotype distribution of $65.14 \%$, GT genotype $31.9 \%$, and TT genotype $3.67 \%$ [12]. Asian SLE patients themselves are dominated by the wild-type GG homozygous genotype and the GT heterozygous genotype, while the TT mutant homozygous genotype frequency is still not widely found. The same thing was also found in a study conducted by Gupta et al. in 2018. The GG genotype was more common in SLE patients in India, which were $54.1 \%$, while the GT mutant heterozygous genotype was $36.5 \%$, and the TT mutant homozygous was only $9.4 \%$ [22]. However, different results were shown in the Latin American population. Research conducted by Moreno-Eutimio et al. (2020) showed the GT genotype was more prominent than other genotypes, which was $47.1 \%$ compared to the GG $(30.4 \%)$ and TT (22.5\%) [16]. The comparison between the results of this study and the genotypic distribution data in SLE patients obtained from other countries can be seen in table 4 .

Table 4: Comparison of genotype and allele frequency on SLE patients based on race or ethnicity

\begin{tabular}{|c|c|c|c|c|c|c|}
\hline TNFSF4 SNP & Genotypes and Allele & Chinese [10] & Malaysian [10] & $\begin{array}{l}\text { North Indian } \\
{[20]}\end{array}$ & $\begin{array}{l}\text { Latin } \\
\text { American [15] }\end{array}$ & $\begin{array}{l}\text { Indonesian } \\
\text { (Bandung)* }\end{array}$ \\
\hline \multirow{5}{*}{ rs2205960 } & GG & $50.9 \%$ & $65.14 \%$ & $54.1 \%$ & $30.4 \%$ & $65.48 \%$ \\
\hline & GT & $39.9 \%$ & $31.19 \%$ & $36.5 \%$ & $47.1 \%$ & $29.76 \%$ \\
\hline & TT & $9.8 \%$ & $3.67 \%$ & $9.4 \%$ & $22.5 \%$ & $4.76 \%$ \\
\hline & $\mathrm{T}$ allele & $29.5 \%$ & $19.27 \%$ & $27.7 \%$ & $46.1 \%$ & $19.64 \%$ \\
\hline & G allele & $70.5 \%$ & $80.73 \%$ & $72.3 \%$ & $53.9 \%$ & $80.36 \%$ \\
\hline
\end{tabular}

${ }^{*}$ In this research

Meanwhile, studies evinced the normal populations are dominated by GG genotype in Chinese (56.6\%), Malaysian (66.67\%), and Indian populations $(60.5 \%)[12,22]$. Compared with the population of SLE patients, the normal population showed a greater number of GG genotypes, as can be seen in table 5 . In the Chinese and Malaysian populations, a greater percentage of GT genotypes were present in
SLE patients compared to the normal population, and only the Chinese population showed a greater percentage of TT genotypes in SLE patients than in the normal population $(9.8 \%$ and $6.1 \%$, respectively) [12]. Another difference was found in the normal population in Latin America, where the GT genotype (46.3\%) had a greater percentage than the GG genotype (37.6\%) [16].

Table 5: Comparison of genotype and allele frequency on normal populations based on race or ethnicity

\begin{tabular}{|c|c|c|c|c|c|}
\hline TNFSF4 SNP & Genotypes and Allele & Chinese [10] & Malaysian [10] & North Indian [20] & Latin American [15] \\
\hline \multirow[t]{5}{*}{ rs2205960 } & GG & $56.6 \%$ & $66.67 \%$ & $60.5 \%$ & $37.6 \%$ \\
\hline & GT & $37.3 \%$ & $28.95 \%$ & $34 \%$ & $46.3 \%$ \\
\hline & $\mathrm{TT}$ & $6.1 \%$ & $4.39 \%$ & $5.5 \%$ & $16.1 \%$ \\
\hline & $\mathrm{T}$ allele & $24.8 \%$ & $18.86 \%$ & $22.5 \%$ & $39.2 \%$ \\
\hline & $\mathrm{G}$ allele & $75.2 \%$ & $81.14 \%$ & $77.5 \%$ & $60.8 \%$ \\
\hline
\end{tabular}

The meta-analysis conducted study showed the $\mathrm{T}$ allele was associated with SLE in European and Asian ethnicities. This study also showed that the $\mathrm{T}$ allele is rare in populations originating from Africa, while European and Asian populations show a higher frequency of the $\mathrm{T}$ allele than the African populations. These differences reflect the genetic heterogeneity of SLE among the world populations [10]. Another meta-analysis was carried out by Wang et al. (2019) and Lee et al. (2012) stated similar results, which found a significant association between the T allele of rs2205960 and SLE in all European and Asian subjects. A significant association was also found in the TT genotype with SLE in the same study $[12,21]$. The association of the T allele of the TNFSF4 gene rs2205960 with SLE in Hispanic and East Asian races was also found in a study by Manku et al. in 2013 [15].

Other research stated that the presence of T allele in both GT and TT genotypes correlates with higher expression of OX40L protein in the cell surface $[8,10]$. The $0 X 40-0 X 40 \mathrm{~L}$ interaction regulates the expansion, differentiation, and activity of $\mathrm{T}$ regulatory ( $\mathrm{T}_{\mathrm{reg}}$ ) cells in positive and negative ways depending on the condition or presence of autoimmune disorders [24]. The presence of OX40-0X40L interaction causes inhibition of the formation of $\mathrm{T}_{\text {reg }}$ cells. Therefore, increased cell surface OX40L levels may lead to increased autoantibody and immune complex formation due to $\mathrm{B}$ cell proliferation and differentiation, as well as loss of immune tolerance with suppression of $\mathrm{T}_{\text {reg }}$ function and activation of $\mathrm{T}$ helper cells [23-25]. This mechanism contributes to formation of autoantibody and inflammation in SLE patients [26, 27]. It is also known that the T allele of TNFSF4 rs2205960 has a higher binding affinity for the NF$\mathrm{kB}$ protein p65 compared to the $\mathrm{G}$ allele, indicating that the $\mathrm{T}$ allele has a regulatory effect on gene expression [15].

When associated with other SLE comorbidities, a case-control study showed a significantly higher increase in OX40L expression in patients with lupus nephritis compared to healthy controls and SLE patients without lupus nephritis manifestations [28]. This study also found a rise in serum creatinine levels, where high serum creatinine levels are often associated with kidney disorders [29]. A study conducted on SLE patients in China stated that a change in G>T at rs2205960 correlates with renal impairment and low C3 levels, 
while low C3 levels are among the characteristics of glomerulonephritis due to immune deposition [30, 31]. This indicates that the TNFSF4 gene has the potential as a marker of lupus nephritis and shows that certain genetic variants are associated with the development of different phenotypes in SLE [32, 33 ], though the detailed mechanism for its role in the pathogenesis of lupus nephritis is not known with certainty.

Gender differences are known to play a role in the development of SLE, with a higher number of cases being found in women than men. It has been observed that the disease has affected about $80-90 \%$ of women of all reported cases. These data suggest that hormones play an important role in the etiology of SLE [34, 35]. Hormones such as estrogen have anti-inflammatory and pro-inflammatory properties depending on the factors that influence them [36]. Estrogen is known to have a higher immune system reactivity in women and contributes to triggering autoimmune diseases, including SLE [34]. Consequently, only female subjects were used in this study.

This study indicates that SLE patients in Bandung have genotype variations (GG, GT, and TT), which showed the possibility that the TNFSF4 gene rs2205960 influences susceptibility of SLE. However, these results need to be investigated further with a larger sample size and involving a healthy control group to ascertain the impact of the TNFSF4 gene polymorphism rs2205960 as a risk factor for SLE.

\section{LIMITATIONS}

The limitation of this study is that there is a possibility of bias due to the TNFSF4 gene polymorphism at rs2205960 also has associations with other autoimmune diseases, such as Vogt-Koyanagi Harada syndrome, systemic sclerosis, Sjögren syndrome, and primary biliary cirrhosis $[19,37,38]$. The involvement of patients with other autoimmune diseases is unknown due to limited clinical data and no records on comorbidities.

\section{CONCLUSION}

Based on this study, it can be concluded that the genotype distribution of the TNFSF4 gene rs2205960 in SLE patients in Bandung showed three types of genotypes, namely GG, GT, and TT. From 84 DNA samples, 55 patients $(65.48 \%)$ had a GG genotype, 25 patients $(29.76 \%)$ had a GT genotype, and 4 patients (4.76\%) had a TT genotype. Thus, the results of this study indicate a genotype distribution of the TNFSF4 rs2205960 gene that fulfills the HardyWeinberg principle.

\section{ACKNOWLEDGEMENT}

We would like to thank the Laboratory analyst of Genetic and Molecular Laboratory, Padjadjaran University Teaching Hospital, Bandung for technical support.

\section{FUNDING}

This project was supported by a grant from The Ministry of Research, Technology, and Higher Education of the Republic of Indonesia for MIB.

\section{AUTHORS CONTRIBUTIONS}

AAK was responsible for data interpretation, statistical analysis, and article writing. GBK were responsible for sample collecting, sample selection, and performing genotyping analysis. EW, MSP, and DRF undertook data processing. RA supervised the writing process. LH and MIB supervised the project and revised the article.

\section{CONFLICTS OF INTERESTS}

The author(s) declared no potential conflicts of interest in this study.

\section{REFERENCES}

1. Maidhof W, Hilas O. Lupus: an overview of the disease and management options. PT. 2012;37(4):240-9. PMID 22593636.

2. Ali A, Sayyed Z, Ameer MA, Arif AW, Kiran F, Iftikhar A, Iftikhar W, Ahmad MQ, Malik MB, Kumar V, Dass A, Sami SA, Sapna F, Waqas N. Systemic lupus erythematosus: an overview of the disease pathology and its management. Cureus. 2018;10(9):e3288. doi: 10.7759/cureus.3288, PMID 30443458.
3. Mok CC, Lau CS. Pathogenesis of systemic lupus erythematosus. J Clin Pathol. 2003;56(7):481-90. doi: 10.1136/jcp.56.7.481, PMID 12835292.

4. McHugh J. Systemic lupus erythematosus: OX40L-expressing B cells promote SLE. Nat Rev Rheumatol. 2017;13(10):572. doi: 10.1038/nrrheum.2017.151, PMID 28878335.

5. Jenkins SJ, Perona Wright G, Worsley AG, Ishii N, MacDonald AS. Dendritic cell expression of OX40 ligand acts as a costimulatory, not polarizing, signal for optimal Th2 priming and memory induction in vivo. J Immunol. 2007;179(6):351523. doi: 10.4049/jimmunol.179.6.3515, PMID 17785785.

6. Karulf M, Kelly A, Weinberg AD, Gold JA. OX40 ligand regulates inflammation and mortality in the innate immune response to sepsis. J Immunol. 2010;185(8):4856-62. doi: 10.4049/ jimmunol.1000404, PMID 20844189.

7. Sibilano R, Pucillo C, Frossi B. Modulation of FceRI-dependent mast cell response by OX40L. Methods Mol Biol. 2014;1155:2330. doi: 10.1007/978-1-4939-0669-7_3, PMID 24788170.

8. Cunninghame Graham DS, Graham RR, Manku H, Wong AK, Whittaker JC, Gaffney PM, Moser KL, Rioux JD, Altshuler D, Behrens TW, Vyse TJ. Polymorphism at the TNF superfamily gene TNFSF4 confers susceptibility to systemic lupus erythematosus. Nat Genet. 2008;40(1):83-9. doi: 10.1038/ng.2007.47, PMID 18059267.

9. Chang YK, Yang W, Zhao M, Mok CC, Chan TM, Wong RW, Lee KW, Mok MY, Wong SN, Ng IO, Lee TL, Ho MH, Lee PP, Wong WH, Lau CS, Sham PC, Lau YL. Association of BANK1 and TNFSF4 with systemic lupus erythematosus in Hong Kong Chinese. Genes Immun. 2009;10(5):414-20. doi 10.1038/gene.2009.16, PMID 19357697.

10. Lu MM, Xu WD, Yang J, Ye QL, Feng CC, Li J, Pan HF, Tao JH, Wang J, Ye DQ. Association of TNFSF4 polymorphisms with systemic lupus erythematosus: A meta-analysis. Mod Rheumatol. 2013;23(4):686-93. doi: 10.1007/s10165-0120708-8, PMID 22850862.

11. Wang JM, Yuan ZC, Huang AF, Xu WD. Association of TNFSF4 rs1234315, rs2205960 polymorphisms and systemic lupus erythematosus susceptibility: a meta-analysis. Lupus. 2019;28(10):1197-204. doi: 10.1177/0961203319862610, PMID 31299880.

12. Chua KH, Ooh YY, Chai HC. TNFSF4 polymorphisms are associated with systemic lupus erythematosus in the Malaysian population. Int J Immunogenet. 2016;43(5):303-9. doi: 10.1111/iji.12287, PMID 27519474.

13. Jacquemin C, Schmitt N, Contin-Bordes C, Liu Y, Narayanan $P$, Seneschal J, Maurouard T, Dougall D, Davizon ES, Dumortier H, Douchet I, Raffray L, Richez C, Lazaro E, Duffau P, Truchetet ME, Khoryati L, Mercié P, Couzi L, Merville P, Schaeverbeke T, Viallard JF, Pellegrin JL, Moreau JF, Muller S, Zurawski S, Coffman RL, Pascual V, Ueno H, Blanco P. OX40 ligand contributes to human lupus pathogenesis by promoting $\mathrm{T}$ follicular helper response. Immunity. 2015;42(6):1159-70. doi: 10.1016/j.immuni.2015.05.012, PMID 26070486.

14. Croft M. Control of immunity by the TNFR-related molecule OX40 (CD134). Annu Rev Immunol. 2010;28:57-78. doi 10.1146/annurev-immunol-030409-101243, PMID 20307208.

15. Manku H, Langefeld CD, Guerra SG, Malik TH, Alarcon-Riquelme M, Anaya JM, Bae SC, Boackle SA, Brown EE, Criswell LA, Freedman BI, Gaffney PM, Gregersen PA, Guthridge JM, Han SH, Harley JB, Jacob CO, James JA, Kamen DL, Kaufman KM, Kelly JA, Martin J, Merrill JT, Moser KL, Niewold TB, Park SY, Pons-Estel BA, Sawalha AH, Scofield RH, Shen N, Stevens AM, Sun C, Gilkeson GS, Edberg JC, Kimberly RP, Nath SK, Tsao BP, Vyse TJ. Trans-ancestral studies fine map the SLE-susceptibility locus TNFSF4. PLOS Genet. 2013;9(7):e1003554. doi: 10.1371/journal.pgen.1003554, PMID 23874208.

16. Moreno-Eutimio MA, Martinez-Aleman CE, Aranda-Uribe IS, Aquino-Jarquin G, Cabello-Gutierrez C, Fragoso JM, BarbosaCobos RE, Saavedra MA, Ramirez-Bello J. TNFSF4 is a risk factor to systemic lupus erythematosus in a Latin American population. Clin Rheumatol. 2021;40(3):929-39. doi: 10.1007/s10067-020-05332-9, PMID 32809147.

17. Sanchez E, Webb RD, Rasmussen A, Kelly JA, Riba L, Kaufman KM, Garcia-de la Torre I, Moctezuma JF, Maradiaga Cecena MA, 
Cardiel Rios MH, Acevedo E, Cucho Venegas M, Garcia MA, Gamron S, Pons Estel BA, Vasconcelos C, Martin J, Tusie-Luna T, Harley JB, Richardson B, Sawalha AH, Alarcon-Riquelme ME. Genetically determined Amerindian ancestry correlates with increased frequency of risk alleles for systemic lupus erythematosus. Arthritis Rheum. 2010;62(12):3722-9. doi: 10.1002/art.27753, PMID 20848568.

18. Zuo XB, Sheng YJ, Hu SJ, Gao JP, Li Y, Tang HY, Tang XF, Cheng H, Yin XY, Wen LL, Sun LD, Yang S, Cui Y, Zhang XJ. Variants in TNFSF4, TNFAIP3, TNIP1, BLK, SLC15A4 and UBE2L3 interact to confer risk of systemic lupus erythematosus in Chinese population. Rheumatol Int. 2014;34(4):459-64. doi: 10.1007/s00296-013-2864-3, PMID 24091983.

19. Zhou XJ, Lu XL, Nath SK, Lv JC, Zhu SN, Yang HZ, Qin LX, Zhao $\mathrm{MH}, \mathrm{Su}$ Y, Shen N, Li ZG, Zhang H. International consortium on the genetics of systemic lupus erythematosus gene-gene interaction of BLK, TNFSF4, TRAF1, TNFAIP3, and REL in systemic lupus erythematosus. Arthritis Rheum. 2012;64(1):222-31. doi: 10.1002/art.33318, PMID 21905002.

20. Lu S, Song S, Hou S, Li H, Yang P. Association of TNFSF4 polymorphisms with vogt-koyanagi-harada and behcet's disease in han Chinese. Sci Rep. 2016;6:37257. doi: 10.1038/srep37257. PMID 27872495.

21. Wise MJ. How to teach the Hardy-Weinberg principle using engaging, non-trivial evolutionary scenarios. Bioscene. 2018;44:28-36

22. Gupta V, Kumar S, Pratap A, Singh R, Kumari R, Kumar S, Aggarwal A, Misra R. Association of ITGAM, TNFSF4, TNFAIP3 and STAT4 gene polymorphisms with risk of systemic lupus erythematosus in a North Indian population. Lupus. 2018;27(12):1973-9. doi: 10.1177/0961203318786432, PMID 30041578.

23. Lee YH, Song GG. Associations between TNFSF4 and TRAF1-C5 gene polymorphisms and systemic lupus erythematosus: A meta-analysis. Hum Immunol. 2012;73(10):1050-4. doi: 10.1016/j.humimm.2012.07.044, PMID 22820624

24. Croft M. The role of TNF superfamily members in T-cell function and diseases. Nat Rev Immunol. 2009;9(4):271-85. doi: 10.1038/nri2526, PMID 19319144.

25. Stüber E, Neurath M, Calderhead D, Fell HP, Strober W. Crosslinking of OX40 ligand, a member of the TNF/NGF cytokine family, induces proliferation and differentiation in murine splenic B cells. Immunity. 1995;2(5):507-21. doi: 10.1016/1074-7613(95)90031-4, PMID 7749983.

26. Bansal Pakala P, Jember AG, Croft M. Signaling through OX40 (CD134) breaks peripheral T-cell tolerance. Nat Med. 2001;7(8):907-12. doi: 10.1038/90942, PMID 11479622.

27. Croft M, So T, Duan W, Soroosh P. The significance of OX40 and OX40L to T-cell biology and immune disease. Immunol Rev. 2009;229(1):173-91. doi: 10.1111/j.1600-065X.2009.00766.X PMID 19426222.

28. Farres MN, Al-Zifzaf DS, Aly AA, Abd Raboh NM. OX40/OX40L in systemic lupus erythematosus: association with disease activity and lupus nephritis. Ann Saudi Med. 2011;31(1):29-34. doi: 10.4103/0256-4947.75775, PMID 21245596.

29. Kellum JA, Lameire N, Aspelin P, Barsoum RS, Burdmann EA, Goldstein SL, et al. Kidney disease: improving global outcomes (KDIGO) acute kidney injury workgroup. KDIGO clinical practice guideline for acute kidney injury. Kidney Int Suppl. 2012;2:1-138.

30. Zhou XJ, Cheng FJ, Qi YY, Zhao MH, Zhang H. A replication study from Chinese supports an association between the lupus-risk allele in TNFSF4 and renal disorder. BioMed Res Int. 2013;2013:597921. doi: 10.1155/2013/597921, PMID 23936824.

31. Hebert LA, Parikh S, Prosek J, Nadasdy T, Rovin BH. Differential diagnosis of glomerular disease: a systematic and inclusive approach. Am J Nephrol. 2013;38(3):253-66. doi: 10.1159/000354390, PMID 24052039

32. Ceccarelli F, Perricone C, Borgiani P, Ciccacci C, Rufini S, Cipriano E, Alessandri C, Spinelli FR, Sili Scavalli A, Novelli G, Valesini G, Conti F. Genetic factors in systemic lupus erythematosus: contribution to disease phenotype. J Immunol Res. 2015;2015:745647. doi: 10.1155/2015/745647.

33. Sanchez E, Nadig A, Richardson BC, Freedman BI, Kaufman KM, Kelly JA, Niewold TB, Kamen DL, Gilkeson GS, Ziegler JT Langefeld CD, Alarcón GS, Edberg JC, Ramsey-Goldman R, Petri M, Brown EE, Kimberly RP, Reveille JD, Vilá LM, Merrill JT, Anaya JM, James JA, Pons-Estel BA, Martin J, Park SY, Bang SY, Bae SC, Moser KL, Vyse TJ, Criswell LA, Gaffney PM, Tsao BP Jacob CO, Harley JB, Alarcón-Riquelme ME, BIOLUPUS and GENLES, Sawalha AH. Phenotypic associations of genetic susceptibility loci in systemic lupus erythematosus. Ann Rheum Dis. 2011;70(10):1752-7. doi: 10.1136/ard.2011.154104, PMID 21719445.

34. Khan WA, Habib S, Khan WA, Alam K, Moinuddin. Enhanced binding of circulating SLE autoantibodies to catechol estrogencopper-modified DNA. Mol Cell Biochem. 2008;315(1-2):14350. doi: 10.1007/s11010-008-9798-1, PMID 18543085.

35. Khan WA. Introductory chapter: systemic lupus erythematosus-different predisposing factors. Lupus. 2017. doi: 10.5772 /intechopen.69277.

36. Straub RH. The complex role of estrogens in inflammation. Endocr Rev. 2007;28(5):521-74. doi: 10.1210/er.2007-0001, PMID 17640948.

37. Gourh P, Arnett FC, Tan FK, Assassi S, Divecha D, Paz G, McNearney T, Draeger H, Reveille JD, Mayes MD, Agarwal SK. Association of TNFSF4 (OX40L) polymorphisms with susceptibility to systemic sclerosis. Ann Rheum Dis. 2010;69(3):550-5. doi: 10.1136/ard.2009.116434, PMID 19778912

38. Kong F, Li JX, Li P, Li YZ, Zhang FC, Zhang J. Association of TNFSF4 polymorphisms with susceptibility to primary Sjögren's syndrome and primary biliary cirrhosis in a Chinese han population. Clin Exp Rheumatol. 2013;31(4):546-51. PMID 23622253. 